\title{
Leyndarhyggja: viðhorf almennings til upplýsingagjafar stjórnvalda og stofnana
}

\section{Jóhanna Gunnlaugsdóttir}

Ágrip: Markmið greinarinnar er að kynna niðurstöður íslenskrar rannsóknar um pað hvort pátttakendur hennar teldu að stjórnvöld leyndu mikilvægum upplýsingum um almannahagsmuni annars vegar og opinber útgjöld hins vegar sæju pau ástæður til pess. Sú tilgáta sem lagt var upp með í ljósi pjóðfélagsumræðunar var að almenningur teldi að upplýsingum væri leynt að einhverju marki eða peim ekki komið meðvitað á framfæri af hálfu stjórnvalda. Spurningalisti var sendur tilviljunarúrtaki úr pjóðskrá í mars 2012 og var svarhlutfall 66,9\%. Könnunin grundvallaðist fræðilega á tengdum könnunum og gögnum um traust til stjórnvalda og áhrif upplýsingalaga á upplýsingagjöf. Helstu niðurstöður könnunarinnar voru að meginporri svarenda taldi að upplýsingum sem vörðuðu almannahagsmuni væri leynt oft eða stundum. Einungis 2-3\% svarenda töldu að pað gerðist aldrei. Meginhluti svarenda taldi að upplýsingum sem vörðuðu opinber útgjöld væri leynt oft eða stundum. Aðeins 3-5\% svarenda töldu að pað gerðist aldrei.

Abstract: Almost two thousand Icelanders were asked whether they believed that public authorities in Iceland concealed important information (either about matters of public interest or about public expenditures) if they saw reason to do so. In light of recent public debates in Iceland, the hypothesis was that the general opinion would be that the authorities do, at times, either conceal information or intentionally fail to disseminate it. The survey questionnaire was sent in March 2012 to a random sample selected from the National Registry. The response rate was $66.9 \%$. The survey was modeled on other data and surveys that have explored trust towards public authorities and the influence of freedom-of-information acts on government information practices. The survey found that a great majority of respondents believed that information of general public interest was often or sometimes kept secret. Only 2-3\% of respondents believed that this never happened. Most respondents believed, as well, that information about public expenditures was often or sometimes kept secret. Only 3-5\% of those surveyed were of the opinion that this never happened.

Citation/Tilvísun: Jóhanna Gunnlaugsdóttir, "Leyndarhyggja: viðhorf almennings til upplýsingagjafar stjórnvalda og stofnana," Samtíd 1 (2013), 3.

http://dx.doi.org/10.12742/samtid.2013.3

Received/Móttekið: 2012-12-06. Accepted/Sampykkt: 2013-05-16. Published/Birt: 2013-10-10.

(c) 2013 Author/Höfundur. This open-access article is published under the terms of the Creative Commons Attribution License, version 3.0 / Greinin er birt i opnum aðgangi undir CC-BY 3.0 leyfi (http://creativecommons.org/licenses/by/3.0) 


\section{Inngangur}

Upplýsingalög eru veigamikil áskorun fyrir stjórnvöld um að skapa umhverfi fyrir aukið gegnsæi. En, leiðir löggjöfin til aukins trausts almennings um rekjanleika og upplýsingagjöf? Í greininni verður meðal annars leitast við að svara peirri spurningu. Upplýsingagjöf er mikilvægur páttur í starfsemi hins opinbera og bæði lagasetning og pjóðfélagsumræða hefur snúist um að auka aðgengi að upplýsingum sem eiga erindi til almennings. Kröfur um að stjórnvöld upplýsi almenning að eigin frumkvæði hafa farið vaxandi og í auknum mæli er litið svo á að almenningur eigi að geta gengið að tilteknum upplýsingum án pess að purfa að biðja um pær sérstaklega, meðal annars með ákveðnum skilyrðum, eða leita peirra í óaðgengilegum gagnabrunnum.

Markmið könnunarinnar sem hér er kynnt var að skoða viðhorf almennings til upplýsingagjafar stjórnvalda og gegnsæis um tiltekna málaflokka, pað er hvort hann teldi upplýsingunum leynt. İ pessu samhengi er litið svo á að upplýsingum sé í raun leynt komi stjórnvöld peim ekki á framfæri að eigin frumkvæði skriflega eða munnlega svo sem í fjölmiðlum og á internetinu. Hvort stjórnvöld í raun leyni almenning upplýsingum eða hvort skortur á upplýsingagjöf kunni að hafa verið ómeðvitaður af opinberri hálfu er aftur á móti utan ramma pessarar rannsóknar. Tilgátan sem lagt var upp með var að almenningur teldi að upplýsingum hjá hinu opinbera væri leynt að einhverju leyti.

Rannsóknarspurningarnar snérust um hvort svarendur teldu stjórnvöld og aðra opinbera aðila leyna mikilvægum upplýsingum sem ættu erindi við almenning og vörðuðu almannahagsmuni annars vegar og opinber útgjöld hins vegar, teldu pau (p.e. stjórnvöld) ástæður til pess. Petta viðfangsefni hefur lítið verið tekið til skoðunar hérlendis en stuðst var við tengdar rannsóknir, upplýsingar og gögn um traust til stjórnvalda, gegnsæi og áhrif upplýsingalaga á upplýsingagjöf.

Í upphafi greinarinnar er fjallað um fræðilegan bakgrunn viðfangsefnisins og pví næst gerð grein fyrir gagnasöfnun og aðferðafræði. Niðurstöðum eru gerð skil í tveimur köflum. Umfjöllun pess fyrri lýtur að pví hvort svarendur teldu að stjórnvöld leyndu almenning mikilvægum upplýsingum sem vörðuðu almannahagsmuni, pað er umhverfis-, velferðar-, heilbrigðis- og menntamál. Sá síðari fjallar á sama hátt um upplýsingar um opinber útgjöld, pað er úthlutun á almannafé (styrki og fjárveitingar, verksamninga til opinberra verkefna o.p.h.). Аð síðustu er samantekt og umræður um rannsóknina.

\section{Bakgrunnur}

Viðfangsefni pessarar rannsóknar virðist lítið hafa verið skoðað áður með svipuðum hætti. Hins vegar hefur (1) traust til ríkisstjórna og annarra stjórnvalda með tilliti til 
gegnsæis og upplýsingagjafar og (2) áhrif upplýsingalaga á gegnsæi, upplýsingagjöf, traust til stjórnvalda, starf peirra og áreiðanleika talsvert verið rannsakað. Líta má á pessa rannsókn sem raunhæft framhald af peim rannsóknum. Rannsóknir um traust og upplýsingalög kallast á við viðfangsefni pessarar rannsóknar og pess vegna pótti áhugavert að skoða rannsóknir og heimildir um pað efni til samanburðar. Fræðimenn hafa haldið pví fram að gegnsæi og bætt upplýsingagjöf feli í sér aukið traust. Pá telja ýmsir að upplýsingar séu ein grunnstoða lýðræðis (Relly og Sabharwal, 2009) og forsendur gegnsæis sé að finna í upplýsingalögum (Grimmelikhuijsen, 2011).

\subsection{Traust til stjórnvalda}

Upplýsingagjöf til almennings er mikilvægur páttur í starfsemi stjórnvalda. Ríkisstjórnir láta vantraust sig miklu skipta par sem gagnkvæmt traust milli ríkisstjórnar og borgaranna er talið nauðsynlegt til pess að pjóðfélagið prífist og forsenda pess að ríkisstjórnin nái árangri (Levi og Stoker, 2000). Ýmsir fræðimenn halda pví fram að bætt upplýsingagjöf og gegnsæi auki traust borgaranna (Piotrowski, 2007; Rawlins, 2007), gegnsæið í sjálfu sér auki traustið (Worthy, 2010), pað leiði til opnari stjórnsýslu (Hood, 2006; Norris, 2001) og auki pekkingu og skilning almennings á ríkisstjórninni (Cook, 2010). Samkvæmt Kjær (2004) stuðlar aukin og bætt upplýsingagjöf að auknu lýðræði, betri frammistöðu og áreiðanlegri stjórnun hjá hinu opinbera.

Allt frá 7. áratug síðustu aldar hefur traust almennings til ríkisstjórna farið dvínandi samfara neikvæðari umfjöllun fjölmiðla í peirra garð (Bok, 2001). Pví hefur verið haldið fram að traustið megi bæta með tíðari og skilvirkari upplýsingagjöf um frammistöðu. Bætt upplýsingagjöf sé mikilvæg samskiptum ríkisstjórnar og borgaranna sem hún pjónar svo og fjölmiðlanna sem hún reiðir sig á að flytji upplýsingarnar til almennings (Berman, 1997; Fairbanks, Plowman og Rawlins, 2007).

Stjórnvöld purfa sem dæmi að veita upplýsingar um ný lög, reglugerðir og lagabreytingar, málefni sem varða almannaheill og alpjóðasamskipti á skjótan og skilvirkan hátt. Upplýsingagjöf stjórnvalda, öndvert við upplýsingagjöf flestra einkafyrirtækja, varðar oft mál upp á líf og dauða eins og við náttúruhamfarir og málefni sem hafa bein áhrif á hag borgaranna, svo sem skatta, kosningar og ýmsar stefnuyfirlýsingar (Liu, Horsley og Yang, 2012). Rökræðan um upplýsingalög og traust er mikilvæg par sem pví er haldið fram í viðtekinni pólitískri umræðu að traust til stjórnvalda hafi farið dvínandi í Vestur-Evrópu og öðrum próuðum lýðræðisríkjum frá pví í lok 7. og byrjun 8. áratugar síðustu aldar. Раð hafi orsakað ýmiss konar pjóðfélagsbreytingar (sjá t.d. Dalton, 2005; Hetherington, 2005). Stjórnmálamenn virðast peirrar skoðunar að auka purfi traust og upplýsingalögum var ætlað að vera lausn á pví. Рað byggðist á peirri 
rökrænu hugmynd að með auknu gegnsæi og heiðarleika yxi einnig traustið (Worthy, 2010).

Pótt fjölmargir fræðimenn telji aukna upplýsingagjöf og gegnsæi stuðla að frekara trausti til ríkisstjórna er talsverður ágreiningur hvað petta varðar. Ýmsir fræðimenn álíta að aukið gegnsæi kunni að leiða til pess að pólitísk hneykslismál, blekkingar og mistök séu gerð opinber sem hafi pá í för með sér ásakanir í garð stjórnvalda (Roberts, 2005; Worthy, 2010) og um leið vantraust á peim. Begar almenningur fái tækifæri til pess að skyggnast bak við tjöldin komi iðulega í ljós að ákvarðanir séu ekki eins skynsamlegar og ætla mætti við fyrstu sýn. Aukin upplýsingagjöf gæti leitt í ljós vangetu stjórnvalda til pess að leysa ýmis viðfangsefni og pannig dregið úr trausti (Cook, 2010). Aukinni upplýsingagjöf og gegnsæi fylgir mikið magn upplýsinga sem pó leiðir ekki endilega til aukins trausts. Internetið gerir mögulegt að veita aðgang að gríðarlegu magni upplýsinga, meðal annars um ákvarðanir ríkisstjórna, stefnur og frammistöðu (Curtin og Meijer, 2006), sem leiðir oft til ofgnóttar (information overload) (Margetts, 2006) og misvísandi skilaboða (O’Neill, 2002). Petta kynni vissulega að leiða af sér ýmiss konar spuna (spin) svo sem jákvæðar túlkanir á málefnum og gerðum, birtingu óviðkomandi upplýsinga eða hreinlega ósannindi (Gaber, 2000; Snell, 2002).

Í könnun Pew Research Center á viðhorfum almennings í Bandaríkjunum til ríkisstjórnarinnar kom í ljós að traust borgaranna til hennar féll niður í 17\% árið 1994 og aftur í pað hlutfall árið 2008. Petta er lægsta hlutfall sem sést hefur frá pví að slík tölfræði var fyrst birt árið 1958. Hlutfall peirra sem pað ár treystu ríkisstjórninni nær alltaf (most of the time) var 35\% en var hæst 1964 eða 77\% (Pew Research Center for the People and the Press, 2010).

Í netkönnun Capacent, sem fram fór 15.-22. febrúar 2012, var almenningur spurður um traust sitt til 15 stofnana samfélagsins. Úrtaksstærð var 1.393 einstaklingar á aldrinum 18 ára og eldri af öllu landinu, valdir af handahófi. Svarhlutfall var 62\%. I niðurstöðunum kom fram að 10\% Íslendinga báru mikið traust til Alpingis eins og sjá má á mynd 1.

Til eru samfelldar upplýsingar um traust til Alpingis hér á landi frá árinu 1995. Pær sýna að í júní 1995 báru 50\% Î́slendinga mikið traust til Alpingis, 42\% í febrúar 2008 en í febrúar 2009 báru einungis 13\% peirra mikið traust til Alpingis. Traustið hefur farið minnkandi og var komið niður í 10\% í febrúar árið 2012 sem fyrr segir.

Í könnuninni frá í febrúar 2012 báru 15\% Íslendinga mikið traust til borgarstjórnar Reykjavíkur eins og mynd 1 sýnir. Upplýsingar um traust til borgarstjórnar eru til frá 2008. Í febrúar pað ár báru 9\% mikið traust til hennar, 22\% í sama mánuði 2010 og 16\% í peim mánuði 2011 (Capacent, 2012). 
Mynd 1. Traust Íslendinga til Alpingis, 1995-2012, og til borgarstjórnar Reykjavíkur, 2008-2012 (Capacent, 2012).

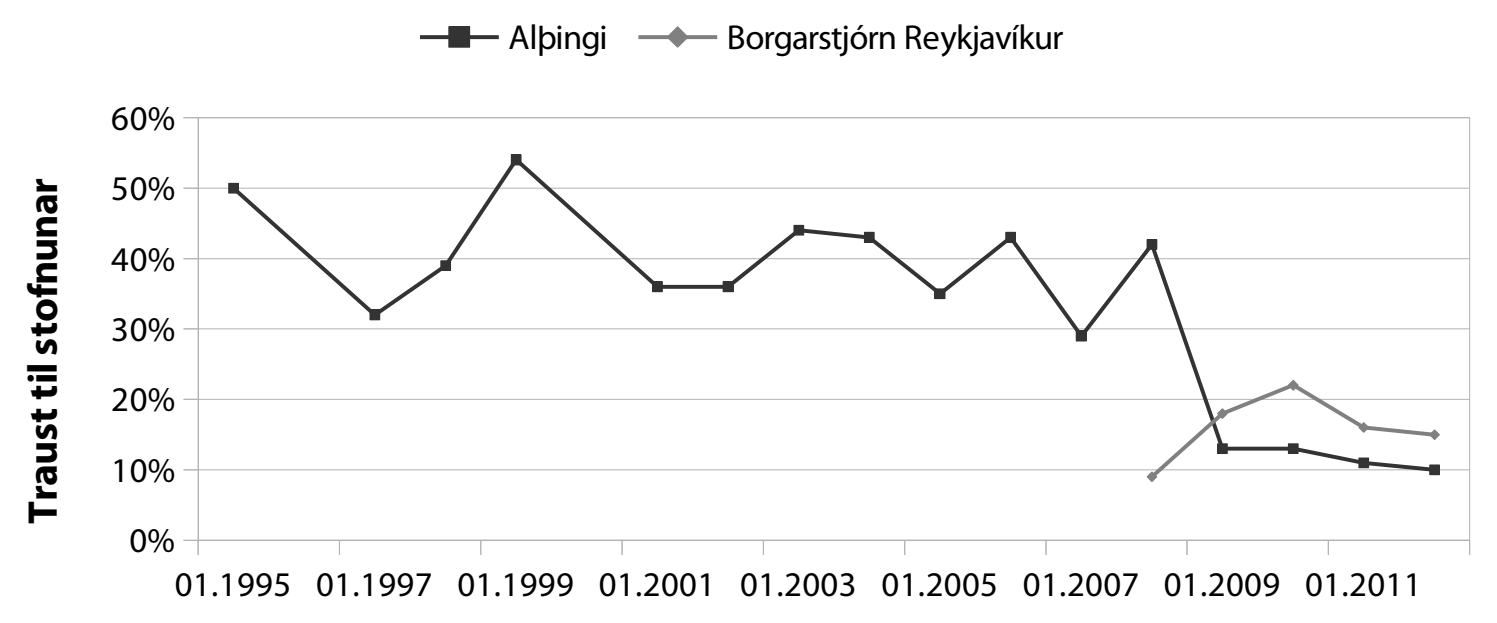

Dagsetning könnunar

\subsection{Upplýsingalög}

Upplýsingalög (Freedom of Information Acts) hafa verið sett í 80-90 löndum og fleiri lönd vinna að slíkri löggjöf (Vleugels, 2011). Svíar eiga heiðurinn af elstu lögum par sem kveðið er á um rétt almennings til pess að fá aðgang að skjölum í fórum hins opinbera, pað er lög frá árinu 1766 um frelsi fjölmiðla og upplýsingafrelsi. Fyrstu upplýsingalög í nútímaskilningi voru sett í Bandaríkjunum 1966. Svipuð lög tóku gildi í Ástralíu, Kanada og á Nýja Sjálandi snemma á 9. áratug síðustu aldar. Í Hollandi tóku upplýsingalög gildi 1980 en ekki fyrr en 2005 í Bretlandi pótt pau hafi verið sampykkt í breska pinginu árið 2000 (Birkinshaw, 2010; Grimmelikhuijsen, 2011; Mendel, 2008; Worthy, 2010) fjórum árum eftir setningu íslenskra upplýsingalaga nr. 50/1996. Upplýsingalög ná til réttar almennra borgara til aðgengis að upplýsingum sem liggja hjá stjórnvöldum pó með vissum takmörkunum (Worthy, 2010) sem varða einkahag, almannaheill og pjóðaröryggi.

Fylgismenn upplýsingalaga hafa pá trú að pau stuðli að frekari próun lýðræðis og upplýsingalög eru í auknum mæli talin undirstaða mannréttinda (Darch og Underwood, 2010). Gegnsæið sem fæst með upplýsingalögum gæti leitt af sér aukið réttlæti, íbúalýðræði og traust sem gæti síðan leitt til áhrifaríkra breytinga á ríkisstjórn, stjórnmálum og ásýnd pjóðarinnar (Stiglitz, 2003). Niðurstöður könnunar á aðgengi að upplýsingum á alpjóðavísu á grundvelli upplýsingalaga gáfu til kynna að oftsinnis hefði gegnsæi aukist svo og íbúapátttaka og upplýsingagjöf til borgaranna af hálfu stjórnvalda (Mendel, 2008). Niðurstöður breskrar könnunar sem birtar voru 2010 bentu til pess að gildistaka upplýsingalaga hefði leitt til aukins gegnsæis og opnari og áreiðan- 
legri stjórnsýslu. Traust til stjórnvalda hefur hins vegar ekki aukist að sama skapi ef marka má könnunina (Hazell og Worthy, 2010; Worthy, 2010).

Andstæðingar upplýsingalaga hafa efasemdir um möguleika og gildi laganna. Beir benda á að andstaða gegn breytingum sé rík hjá opinberum og pólitískum stofnunum og viðhorfið sé að viðhalda skuli núverandi fyrirkomulagi og halda pví fyrir sig. Pað geri breytingar bæði erfiðar og óaðlaðandi (Pierson, 2000). Upplýsingalög kynnu að vera áhrifarík ógnun við valdið sem leyndarhyggjunni fylgir. Pað færi fyrir lítið með gegnsæi og opinni stjórnsýslu. Pví hefur einnig verið haldið fram að leynd kynni jafnvel að aukast með tilkomu upplýsingalaga (Worthy, 2010) og hægt yrði að komast hjá pví að gera mál opinber með pví að forðast skjalfestingu peirra og skráningu. Tough (2011) ræðir að ótti við upplýsingaleka geti leitt til pess að upplýsingar yrðu síður skjalfestar og skjöl yrðu síður mynduð. Samkvæmt könnun Hazell og Glover (2011) á pví hvort upplýsingalög hefðu breytt vinnubrögðum breskra stjórnvalda kom í ljós að breytingin var léttvæg. Upplýsingalögin reyndust ekki nógu öflug til pess að stuðla að verulegum breytingum hvorki til góðs, eins og stuðningsmenn vonuðu, né til ills eins og andstæðingar óttuðust. Að vísu hefðu upplýsingar verið gerðar opinberar í auknum mæli en viðhorf og áhyggjur stjórnvalda með tilliti til upplýsinga réðust af öðrum öflum, til dæmis hættunni sem orsakaðist af leka og lekaveitum af ýmsu tagi. Spár um hrollvekjandi áhrif óhlutdrægni og skjalfestingar hefðu ekki ræst pó svo að ráðherrar héldu áfram að hafa áhyggjur af áhrifum laganna á skjalahald og umræður (Hazell og Glover, 2011; Hazell, Worthy og Glover, 2010).

Kerfisbundin upplýsinga- og skjalastjórn sem stuðlar að greiðari aðgangi að réttum og áreiðanlegum upplýsingum ætti að auðvelda stjórnvöldum að fylgja upplýsingalögum (Flinn og Jones, 2009; Jóhanna Gunnlaugsdóttir, 2011). Fræðimenn á sviði upplýsinga- og skjalastjórnar hafa hin síðari ár, meðal annars í Bretlandi par sem upplýsingalög tóku seint gildi, skoðað og rætt tengsl á milli fræðigreinar sinnar og pess að hlíta upplýsingalögum (Shepherd, Stevenson og Flinn, 2010). Peir hafa meðal annars kannað hvernig og hvort opinberir aðilar í Bretlandi undirbjuggu sig fyrir gildistöku upplýsingalaga í janúar 2005 (sjá t.d. Screene, 2005), áhrif upplýsingalaga á upplýsingaog skjalastjórn hjá hinu opinbera (sjá t.d. Shepherd og Ennion, 2007) og upplýsingaog skjalastjórn hjá enskum sveitarstjórnum með tilliti til upplýsingalaga (Shepherd, Stevenson og Flinn, 2011).

\subsection{Viðmið og áskoranir um gegnsæi, upplýsingagjöf og skjalfestingu}

Í samræmi við íslensk lög er stjórnvöldum ætlað að skjalfesta, skrá og miðla tilteknum upplýsingum. Í skýrslu rannsóknarnefndar Alpingis (Páll Hreinsson, Sigríður Bene- 
diktsdóttir og Tryggvi Gunnarsson, 2010) kemur víða fram að ýmsu hafi verið ábótavant hjá stjórnsýslunni hvað varðar rekjanleika, skjalfestingu og skráningu upplýsinga.

Í skýrslu rannsóknarnefndarinnar kemur fram að við athugun á gögnum úr innra starfi ríkisstjórnar og Stjórnarráđs Î́slands, frá 2007 og 2008, hafi ekki gætt samræmis í verklagi hvað varðar skráningu upplýsinga. Hér er um að ræða upplýsingar sem fóru á milli mismunandi stjórnvalda, stjórnvalda og einkaaðila og íslenskra stjórnvalda og stjórnvalda annarra ríkja. Tekið er fram að mikilvægt sé í framtíðinni að viðhafa vandaðra verklag hvað varðar skráningu, aðgengi og öryggi skjala og upplýsinga. Mikilvægt er talið að setja samræmdar reglur um skjalfestingu og skráningu tiltekinna upplýsinga svo sem ákvarðanir stjórnvalds. Í skýrslunni er rætt að hagsmuna ríkisins verði ekki gætt án skilvirkrar skráningar upplýsinga hjá Stjórnarráðinu. Ýmsir hafa bundið vonir við að skýrslan sé stjórnvöldum leiðarljós varðandi upplýsingamál og aðgengi að skjölum (Jóhanna Gunnlaugsdóttir, 2011). Önnur viðmið og áskoranir eru til dæmis:

— Lög sem taka til skjala og upplýsinga, meðal annars hvað varðar skráningu upplýsinga, afgreiðslu mála, miðlun og upplýsingaskyldu. Hér má nefna lög um Pjóðskjalasafn Íslands nr. 66/1985 ásamt síðari breytingum, stjórnsýslulög nr. 37/1993, lög um persónuvernd og meðferð persónuupplýsinga nr. 77/2000, upplýsingalög nr. 50/1996 og ný upplýsingalög nr. 140/2012 sem leyst hafa pau eldri af hólmi.

- Skýrsla stjórnlaganefndar par sem orðið gegnsæi/gagnsæi kemur víða fyrir. Par kemur meðal annars fram skýr krafa um að styrkja beri inniviði stjórnsýslunnar og auka gegnsæi (Guðrún Pétursdóttir, 2011).

- Frumvarp stjórnlagaráðs. İ 15. gr. kafla um mannréttindi og náttúru er lögð áhersla á upplýsingarétt og leitast við að herða á frumkvæðisskyldu ríkisins við söfnun, birtingu og miðlun upplýsinga. Pá er í 35. gr. kveðið á um að stjórnvöldum beri að upplýsa almenning um umhverfi og náttúru, svo sem umhverfismengun og náttúruvá (Stjórnlagaráð, 2011).

\subsection{Fjölmiðlaumræðan og hvati könnunarinnar}

Kveikjan að rannsókninni sem hér er til umfjöllunar er úrklippusafn höfundar sem samanstendur af efni úr fjölmiðlum frá síðustu tveimur áratugum tæpum og varðar aðgengi að upplýsingum og rétt almennings til upplýsinga samkvæmt lögum. Pegar úrklippusafnið er skoðað finnast mörg dæmi pess að upplýsingagjöf stjórnvalda virðist hafa verið ábótavant og upplýsingum stundum leynt um mikilvæg mál. Hér er ekki rúm til pess að rekja öll dæmin en nokkur pekkt skulu nefnd, nokkur pau sem allmargir hafa skrifað um og rætt og fengið hafa víðtæka umfjöllunun í fjölmiðlunum. Annars vegar eru tekin dæmi um ákvarðanir stjórnvalda sem skiptu pjóðina máli og almenningur var ekki upplýstur um í fyrstu og hins vegar dæmi um ákvarðanir sem 
kynnu jafnvel að hafa haft í för með sér verulegar fjárhagslegar skuldbindingar fyrir almenning yrðu pær að veruleika. Eftirfarandi eru dæmi um fyrri flokkinn:

- Ekki var ljóst hverjir tóku ákvörðun um stuðning Îslendinga við innrás Bandaríkjamanna í Írak á sínum tíma og hvar og hvenær sú ákvörðun var tekin. Рað kom pjóðinni í opna skjöldu pegar nafn Íslands birtist á lista yfir „hinar viljugu pjóðir“. Engin skrifleg samtímaheimild virðist til um hvenær, hvar og af hverjum ákvörðun pessi var tekin (Jóhanna Gunnlaugsdóttir, 2005).

- Rétt fyrir gerð könnunarinnar, í janúar og febrúar 2012, var mikil umfjöllun í fjölmiðlum um leynd, eða skort á upplýsingum hjá eftirlitsstofnunum, varðandi hugsanlega skaðsemi iðnaðarsalts sem notað var til matvælaframleiðslu (sjá t.d. „Iðnaðarsalt átti ekki að nota í matvæli“, 2012), brjóstapúða með ólöglegu iðnaðarsílíkoni sem ógnað gæti heilsu kvenna (sjá t.d. Ingveldur Geirsdóttir 2012a, 2012b) og kadmíum í áburði sem mældist yfir mörkum en salan samt heimiluð (sjá t.d. „Mistök að veita ekki upplýsingar án tafar“, 2012).

Eftirfarandi dæmi varða síðari flokkinn, pað er að segja ákvarðanir um jafnvel verulegar fjárhagslegar skuldbindingar sem sumir töldu að hefðu átt að fara leynt:

- Samningur, sem nefndur hefur verið Icesave I, var gerður af samninganefnd undir forystu Svavars Gestssonar í lok maí 2009. Hann áttu alpingismenn að sampykkja óséðan (sjá t.d. „Enn á ný leyna stjórnvöld gögnum um Icesave“, 2009) og talið var að hann hefði verið undirritaður án pess að til staðar væri traustur meirihlutastuðningur í pinginu (Sigurður Kári Kristjánsson, 2010). Pegar skorið hafði verið úr ágreiningsefnum af EFTA-dómstólnum í lok janúar 2013 var pað mat InDefence-hópsins að sá samningur hefði kostað skattgreiðendur 213 milljarða króna til pess tíma (Hörður Ægisson, 2013).

- Prátt fyrir ítrekaðar fyrirspurnir og fjölmiðlaumfjöllun virðast fullnægjandi skýringar á lögmæti fjárráðstafana vegna Byrs, Sparisjóðs Keflavíkur, VBS fjárfestingarbanka, Sögu Capital og Sjóvár ekki veittar (sjá t.d. Jóhanna Gunnlaugsdóttir, 2011). - Á sínum tíma taldi fjármálaráðherra tölvupóst vera „einkapóst“, ekki opinberar upplýsingar, prátt fyrir að tölvupósturinn fjallaði um greiðslur af almannafé, 30.000 .000 kr., til Árbótar í Pingeyjarsýslu við lokun meðferðarheimilisins 2010 (sjá t.d. Jóhanna Gunnlaugsdóttir, 2011; Stígur Helgason og Trausti Hafliðason, 2010).

Gagnasafn fjölmiðlaefnisins er mikið að vöxtum. คað samanstendur af efni úr fjölmiðlum auk bóka, skýrslna og greinargerða pessa efnis. Safnið telur hundruð greina og rita og bíður pess að verða greint síðar með aðferðum orðræðugreiningar (discourse analysis) (Fairclough, 1993/2002; Hennink, Hutter og Bailey, 2011). 
Af framangreindum dæmum má ráða að full ástæða var til pess að kanna viðhorf almennings til upplýsingagjafar stjórnvalda. Hér á eftir verður gerð grein fyrir aðferðafræði könnunarinnar. Stjórnvöldum í pessum skilningi er skipt í ríkisstjórn, ráðuneyti, sveitarfélög og stofnanir peirra og pjónustu- og eftirlitsstofnanir á vegum ríkisins.

\section{Aðferðafræði}

Könnunin var gerð í mars og apríl 2012. Útbúinn var spurningalisti og notast við raðskala (ordinal scale); oft, stundum, sjaldan, aldrei (Neuman, 2011; Saunders, Lewis og Thornhill, 2003). Með pessu mælitæki var stefnt að pví að ná fram markmiði könnunarinnar og svara rannsóknarspurningunum.

Könnunin var send á netpanel Félagsvísindastofnunar Háskóla Íslands sem samanstendur af fólki 18 ára og eldra á landinu öllu sem sampykkt hefur að taka pátt í vefkönnunum á vegum stofnunarinnar. Netpanellinn byggist á tilviljunarúrtaki úr pjóðskrá. Söfnun í netpanel á sér stað jafnt og pétt yfir árið. Til pess að uppfylla strangar aðferðafæðilegar reglur um val á pátttakendum í netpanel er hann reglulega uppfærður, pað er pannig að hann samsvari dreifingu í pýði með tilliti til kyns, aldurs, búsetu, menntunar og tekna. Sökum pessa er hægt að alhæfa um niðurstöður rannsókna sem byggjast á svörum úr honum. Tekið var 1.898 manna tilviljunarúrtak úr netpanelnum. Pátttakendur hans svöruðu könnuninni á vefnum á tímabilinu 15. mars til 16. apríl 2012. Alls bárust 1.270 svör og er svarhlutfall pví 66,9\% (sjá töflu 1).

\section{Tafla 1. Framkvomd könnunarinnar.}

\begin{tabular}{lr}
\hline Upplýsingasöfnun & $15.03 .12-16.04 .12$ \\
Framkvæmdarmáti & Netkönnun \\
Fjöldi í úrtaki & 1.898 \\
Fjöldi svarenda & 1.270 \\
Svarhlutfall & $66,9 \%$ \\
\hline
\end{tabular}

Í könnuninni reyndist hlutfall karla og kvenna og skipting svarenda eftir landsvæðum sambærileg kynjahlutfalli Îslendinga og búsetu. Munur er á aldursdreifingu svarenda og Íslendinga almennt en svörun var lakari í yngsta aldurshópnum en búist var við. Gögnin voru pví vigtuð til pess að úrtak endurspeglaði pýðið með tilliti til aldurs.

Svör voru greind með viðeigandi tölfræði. Niðurstöður sýna hlutföll og fjölda svara skipt niður eftir bakgrunnspáttunum kyni, aldri, búsetu, menntun, stöðu á vinnumarkaði, starfsstétt, tekjum, stjórnmálaskoðun og hjúskaparstöðu.

Netpanellinn var athugaður áður en könnunin var send út en par sem hliðstæð könnun hafði ekki verið gerð áður hér á landi var ekki vitað fyrirfram hvort líklegt væri 
að allar breytur í netpanelnum skiptu máli varðandi afstöðu svarenda pegar spurt var um viðhorf til upplýsingagjafar stjórnvalda. Pví var ákveðið að skoða svörin með tilliti til allra breytna sem netpanellinn bauð upp á. Einungis er fjallað um niðurstöður með hliðsjón af pessum breytum að pví marki sem pær sýna mun á afstöðu.

Marktektarprófið kí-kvaðrat var notað til pess að meta hvort tölfræðilega marktækur munur væri á hlutföllum mismunandi hópa. Tölfræðileg marktekt pýðir í fyrsta lagi að innan við 5\% líkur séu á pví að munur sem sést í hópi svarenda sé kominn til af tilviljun $(p<0,05)$ og pví má segja með 95\% vissu að munurinn sem birtist í úrtakinu hafi einnig verið til staðar meðal Íslendinga í mars og apríl 2012. Í öðru lagi má segja að munurinn sé marktækur miðað við 99\% öryggi $(p<0,01)$ og loks að fullyrða megi með 99,9\% vissu að munurinn sé til staðar í pýði $(p<0,001)$.

Í næstu köflum verður farið yfir niðurstöður spurninga um viðhorf almennings til upplýsingagjafar stjórnvalda og stofnana. Spurningarnar eru einnig greindar eftir bakgrunnspáttum og pær sem áhugaverðastar póttu ræddar.

\section{Upplýsingar sem varða almannahagsmuni}

Í könnuninni voru pátttakendur spurðir hvort peir teldu að opinberir aðilar leyndu mikilvægum upplýsingum sem ættu erindi við almenning og vörðuðu almannahagsmuni, sæju peir ástæður til pess. Málefnin sem hér um ræðir vörðuðu umhverfis-, velferðar-, heilbrigðis- og menntamál. Pátttakendur voru spurðir hvort peir teldu að opinberu aðilarnir gerðu pað oft, stundum, sjaldan eða aldrei. Í næstu undirköflum verður greint frá niðurstöðunum.

Tafla 2. Telur pú að eftirtaldir opinberir aðilar leyni mikilvoegum upplýsingum sem eiga erindi við almenning og varða almannahagsmuni (umhverfis-, velferðar-, heilbrigðis- og menntamál) oft, stundum, sjaldan eða aldrei, sjái peir ástæður til pess? - Ríkisstjórnin.

\begin{tabular}{|c|c|c|c|c|c|}
\hline & $\begin{array}{l}\text { Vigtaður } \\
\text { fjöldi }\end{array}$ & $\begin{array}{l}\text { Raunveru- } \\
\text { legur fjöldi }\end{array}$ & Hlutfall & $\begin{array}{r}\text { ikmörk } \\
(+/-)\end{array}$ & Hlutfall \\
\hline Oft & 581 & 578 & $50 \%$ & $2,9 \%$ & -50\% \\
\hline Stundum & 464 & 471 & $40 \%$ & $2,8 \%$ & $40 \%$ \\
\hline Sjaldan & 105 & 107 & $9 \%$ & $1,6 \%$ & 9\% \\
\hline Aldrei & 22 & 20 & $2 \%$ & $0,8 \%$ & - $2 \%$ \\
\hline Fjöldi svara & 1172 & 1176 & $100 \%$ & & \\
\hline Veit ekki & 84 & 78 & & & \\
\hline Vil ekki svara & 17 & 16 & & & \\
\hline Alls & 1273 & 1270 & & & \\
\hline
\end{tabular}




\subsection{Ríkisstjórnin}

Meginporri svarenda eða 90\% taldi að ríkisstjórnin leyndi oft eða stundum mikilvægum upplýsingum sem ættu erindi við almenning og vörðuðu almannahagsmuni, sæi hún ástæður til pess. Einungis $2 \%$ svarenda töldu að hún gerði pað aldrei (sjá töflu 2).

Við bakgrunnsgreiningu kom marktækur munur í ljós innan páttanna menntun $(p<0,001)$, starfsstétt $(p<0,01)$ og stjórnmálaflokkur $(p<0,001)$. Pað var mat 94\% svarenda sem höfðu verklegt framhaldsnám eða iðnmenntun að baki að ríkisstjórnin leyndi oft eða stundum upplýsingum sem vörðuðu almannahagsmuni en síður skoðun svarenda sem lokið höfðu framhaldsnámi í háskóla, eða 82\%. Samkvæmt 94\% iðnaðarmanna, sérhæfðra starfsmanna og tækna leyndi ríkisstjórnin slíkum upplýsingum oft eða stundum en lægra hlutfall stjórnenda og sérfræðinga var peirrar skoðunar, eða 86\%. Af peim sem studdu Framsóknarflokkinn töldu 93\% svarenda að ríkistjórnin leyndi oft eða stundum pess háttar upplýsingum og $96 \%$ peirra sem studdi Sjálfstæðisflokkinn. Hins vegar taldi mun lægra hlutfall stuðningsmanna Samfylkingarinnar og Vinstri grænna, eða 74\%, að ríkisstjórnin gerði pað oft eða stundum (sjá nánari umfjöllun í töflu 7).

\subsection{Ráduneytin}

Meginhluti svarenda eða $88 \%$ taldi að ráðuneytin leyndu oft eða stundum mikilvægum upplýsingum sem ættu erindi við almenning og vörðuðu almannahagsmuni, sæju pau ástæður til pess. Aðeins 2\% svarenda töldu að pau gerðu pað aldrei (sjá töflu 3).

Tafla 3. Telur pú að eftirtaldir opinberir aðilar leyni mikilvogum upplýsingum sem eiga erindi við almenning og varða almannahagsmuni (umhverfis-, velferðar-, heilbrigðis- og menntamál) oft, stundum, sjaldan eða aldrei, sjái peir ástæður til pess? - Ráðuneyti.

\begin{tabular}{|c|c|c|c|c|c|}
\hline & $\begin{array}{l}\text { Vigtaður } \\
\text { fjöldi }\end{array}$ & $\begin{array}{l}\text { Raunveru- } \\
\text { i legur fjöldi }\end{array}$ & Hlutfall & $\begin{array}{r}\text { Vikmörk } \\
(+/-)\end{array}$ & Hlutfall \\
\hline Oft & 541 & 547 & $47 \%$ & $2,9 \%$ & $47 \%$ \\
\hline Stundum & 474 & 476 & $41 \%$ & $2,8 \%$ & $41 \%$ \\
\hline Sjaldan & 118 & 119 & $10 \%$ & $1,7 \%$ & $10 \%$ \\
\hline Aldrei & 22 & 19 & $2 \%$ & $0,8 \%$ & - $2 \%$ \\
\hline Fjöldi svara & 1155 & 1161 & $100 \%$ & & \\
\hline Veit ekki & 102 & 94 & & & \\
\hline Vil ekki svara & 16 & 15 & & & \\
\hline Alls & 1273 & 1270 & & & \\
\hline
\end{tabular}


Marktækur munur var eftir kyni $(p<0,01)$, menntun $(p<0,01)$, stöðu á vinnumarkaði $(p<0,05)$, stjórnmálaflokki $(p<0,001)$ og hjúskaparstöðu $(p<0,05)$. Hærra hlutfall karla en kvenna taldi að ráðuneytin leyndu oft upplýsingum sem vörðuðu almannahagsmuni. Pegar svarmöguleikanum stundum var bætt við urðu hlutföllin hins vegar nær pau sömu fyrir bæði kynin, eða $88 \%$ hjá körlum og $89 \%$ hjá konum. Rúmlega 92\% peirra sem voru með verklegt framhaldsnám eða iðnmenntun töldu að ráðuneytin leyndu oft eða stundum slíkum upplýsingum en lægra hlutfall peirra sem höfðu lokið framhaldsnámi í háskóla var peirrar skoðunar eða 82\%. Nokkru hærra hlutfall nema, eða $86 \%$, taldi ráðuneytin leyna oft eða stundum slíkum upplýsingum en allir peir sem voru í fæðingarorlofi eða heimavinnandi töldu pau gera slíkt. Af peim sem studdu Framsóknarflokkinn töldu 92\% svarenda að ráðuneytin leyndu oft eða stundum pess háttar upplýsingum og 91\% sjálfstæðismanna var peirrar skoðunar. Hins vegar töldu færri stuðningsmanna Samfylkingarinnar og Vinstri grænna að ráðuneytin gerðu pað oft eða stundum (S 22\% oft, 50\% stundum og VG 24\% oft, 54\% stundum).

\subsection{Sveitarfélög og stofnanir peirra}

Tæplega 80\% svarenda töldu sveitarfélögin og stofnanir peirra leyna oft eða stundum mikilvægum upplýsingum sem ættu erindi við almenning og vörðuðu almannahagsmuni, sæju pau ástæður til pess (26\% oft, 52\% stundum). Einungis $2 \%$ svarenda töldu að pau gerðu pað aldrei en $20 \%$ að pau gerðu pað sjaldan.

Marktækur munur var innan páttanna búseta $(p<0,05)$, stjórnmálaflokkur $(p<$ $0,001)$ og hjúskaparstaða $(p<0,05)$. Að mati $80 \%$ íbúa höfuðborgarsvæðisins leyndu sveitarfélög og stofnanir peirra oft eða stundum upplýsingum sem vörðuðu almannahagsmuni, prír fjórðu eða 75\% íbúa landsbyggðarinnar töldu pau leyna slíkum upplýsingum. Liðlega 80\% peirra sem studdi Framsóknarflokkinn taldi að sveitarfélögin og stofnanir peirra leyndu slíkum upplýsingum oft eða stundum og 73\% peirra sem studdu Sjálfstæðisflokkinn. Hins vegar töldu 65\% samfylkingarmanna að pau gerðu pað oft eða stundum og 73\% Vinstri grænna voru peirrar skoðunar.

\subsection{Pjónustustofnanir á vegum ríkisins}

Rúmlega prír fjórðu svarenda taldi að pjónustustofnanir á vegum ríkisins leyndu oft eða stundum mikilvægum upplýsingum sem ættu erindi við almenning og vörðuðu almannahagsmuni, sæju pær ástæður til pess (28\% oft, 48\% stundum). Aðeins 3\% svarenda álitu að pað gerðu pær aldrei en $21 \%$ að pær gerðu pað sjaldan.

Í ljós kom að marktækur munur var eftir kyni $(p<0,05)$, aldri $(p<0,01)$, menntun $(p<0,01)$, stöðu á vinnumarkaði $(p<0,05)$, stjórnmálaflokki $(p<0,001)$ og hjúskaparstöðu $(p<0,01)$. Hærra hlutfall kvenna en karla taldi að pjónustustofnanir á 
vegum ríkisins leyndu upplýsingum sem vörðuðu almannahagsmuni pegar lögð voru saman svörin oft eða stundum en kynin greindi á um tíðnina. Hærra hlutfall karla taldi petta gerast oft en konur voru ákveðnari í að petta gerðist stundum. Svarendur í tveimur yngstu aldurshópunum (18-39 ára) töldu að stofnanir pessar leyndu upplýsingum sjaldnar en peir sem voru á aldursbilinu 40 ára og eldri. Rúmlega $80 \%$ svarenda sem höfðu verklegt framhaldsnám eða iðnnám töldu að stofnanirnar leyndu upplýsingum oft eða stundum en $65 \%$ svarenda með starfsnám. Tæplega $80 \%$ peirra sem studdu Framsóknarflokkinn og Sjálfstæðisflokkinn töldu pjónustustofnanirnar leyna slíkum upplýsingum oft eða stundum. Aftur á móti töldu $60 \%$ samfylkingarmanna að pær gerðu pað oft eða stundum en 71\% Vinstri grænna var peirrar skoðunar.

\subsection{Eftirlitssofnanir á vegum ríkisins}

Að mati $80 \%$ svarenda leyndu eftirlitsstofnanir á vegum ríkisins oft eða stundum mikilvægum upplýsingum sem ættu erindi við almenning og vörðuðu almannahagsmuni, sæju pær ástæður til pess (37\% oft, $43 \%$ stundum). Samkvæmt $18 \%$ svarenda gerðu pær pað sjaldan en einungis $2 \%$ töldu að slíkt gerðu pær aldrei.

Marktækur munur reyndist vera eftir kyni $(p<0,05)$, aldri $(p<0,05)$, stöðu á vinnumarkaði $(p<0,05)$, stjórnmálaflokki $(p<0,001)$ og hjúskaparstöðu $(p<0,05)$. Tæplega 40\% karla töldu að eftirlitsstofnanir á vegum ríkisins leyndu stundum upplýsingum sem vörðuðu almannahagsmuni en tæplega 50\% kvenna töldu pær gera pað stundum. Hærra hlutfall karla eða 40\% á móti 35\% kvenna taldi pað gerast oft. Pegar svarmöguleikarnir voru lagðir saman var ekki mikill munur milli kynja. Eftir pví sem svarendur voru eldri peim mun algengara var að peir grunuðu eftirlitsstofnanir um leyndarhyggju. Hlutfallið var 72\% í yngsta hópnum (18-29 ára) pegar lögð eru saman svörin oft og stundum en endar í 89\% hjá elsta hópnum (70 ára og eldri). Að mati 73\% nema leyndu stofnanirnar upplýsingum oft eða stundum en rúmlega $90 \%$ eftirlaunapega og atvinnuleitenda álitu að pær gerðu pað. Liðlega prír fjórðu framsóknarmanna töldu eftirlitsstofnanirnar leyna slíkum upplýsingum oft eða stundum og rúmlega 80\% sjálfstæðismanna töldu að pær gerðu slíkt. Hins vegar taldi lægra hlutfall samfylkingarmanna eða 66\% að pær gerðu pað oft eða stundum en 74\% Vinstri grænna voru peirrar skoðunar.

\section{Upplýsingar sem varða opinber útgjöld}

Í könnuninni voru pátttakendur spurðir hvort peir teldu að opinberir aðilar leyndu mikilvægum upplýsingum sem ættu erindi við almenning (skattgreiðendur) og vörðuðu opinber útgjöld, pað er úthlutun á almannafé (styrki og fjárveitingar, verksamninga til opinberra verkefna o.p.h.), sæju peir ástæður til pess. Pátttakendur voru spurðir 
hvort peir teldu að opinberu aðilarnir gerðu pað oft, stundum, sjaldan eða aldrei. Í næstu undirköflum verður greint frá niðurstöðunum.

\subsection{Ríkisstjórnin}

Meginhluti svarenda eða $81 \%$ taldi að ríkisstjórnin leyndi oft eða stundum mikilvægum upplýsingum sem ættu erindi við almenning og vörðuðu opinber útgjöld, sæi hún ástæður til pess. Einungis 4\% svarenda töldu að hún gerði pað aldrei (sjá töflu 4).

Tafla 4. Telur pú að eftirtaldir opinberir aðilar leyni mikilvogum upplýsingum sem eiga erindi við almenning (skattgreiðendur) og varða opinber útgjöld, p.e. úthlutun á almannafé (styrki og fjárveitingar, verksamninga til opinberra verkefna o.p.h.) oft, stundum, sjaldan eða aldrei, sjái peir ástæður til pess? - Ríkisstjórnin.

\begin{tabular}{|c|c|c|c|c|c|}
\hline & $\begin{array}{r}\text { Vigtaður } \\
\text { fjöldi }\end{array}$ & $\begin{array}{l}\text { Raunveru- } \\
\text { legur fjöldi }\end{array}$ & Hlutfall & $\begin{array}{r}\text { Vikmörk } \\
(+/-)\end{array}$ & Hlutfall \\
\hline Oft & 461 & 463 & $43 \%$ & $3,0 \%$ & $43 \%$ \\
\hline Stundum & 407 & 419 & $38 \%$ & $2,9 \%$ & $38 \%$ \\
\hline Sjaldan & 158 & 159 & $15 \%$ & $2,1 \%$ & $15 \%$ \\
\hline Aldrei & 38 & 35 & $4 \%$ & $1,1 \%$ & - $4 \%$ \\
\hline Fjöldi svara & 1064 & 1076 & $100 \%$ & & \\
\hline Veit ekki & 140 & 131 & & & \\
\hline Vil ekki svara & 69 & 63 & & & \\
\hline Alls & 1273 & 1270 & & & \\
\hline
\end{tabular}

Marktækur munur var til staðar eftir kyni $(p<0,05)$, aldri $(p<0,05)$, stöðu á vinnumarkaði $(p<0,05)$, stjórnmálaflokki $(p<0,001)$ og hjúskaparstöðu $(p<0,05)$. Раð var mat 48\% karla að ríkisstjórnin leyndi oft upplýsingum sem vörðuðu opinber útgjöld en 38\% kvenna voru peirrar skoðunar. Liðlega 30\% karla og 46\% kvenna töldu að hún gerði pað stundum. Heldur færri svarendur í yngsta aldurshópinum (18-29 ára) töldu að ríkisstjórnin leyndi oft eða stundum slíkum upplýsingum en svarendur í eldri hópunum fimm (40 ára og eldri). Að mati 84\% framsóknarmanna leyndi ríkisstjórnin slíkum upplýsingum en nokkru hærra hlutfall, eða 89\%, sjálfstæðismanna taldi að hún gerði slíkt. Hins vegar töldu 69\% samfylkingarmanna að hún gerði pað oft eða stundum og 44\% Vinstri grænna voru peirrar skoðunar. Skoðun svarenda er hér greinilega mismunandi pegar afstaða til stjórnmálaskoðana er höfð til hliðsjónar (sjá nánari umfjöllun í töflu 7). 


\subsection{Ráðuneytin}

Rúmlega 80\% svarenda töldu að ráðuneytin leyndu oft eða stundum mikilvægum upplýsingum sem ættu erindi við almenning og vörðuðu opinber útgjöld, sæju pau ástæður til pess. Einungis 3\% svarenda töldu að pau gerðu pað aldrei (sjá töflu 5).

Tafla 5. Telur pú að eftirtaldir opinberir aðilar leyni mikilvoegum upplýsingum sem eiga erindi við almenning (skattgreiðendur) og varða opinber útgjöld, p.e. úthlutun á almannafé (styrki og fjárveitingar, verksamninga til opinberra verkefna o.p.h.) oft, stundum, sjaldan eða aldrei, sjái peir ástoður til pess? - Ráðuneyti.

\begin{tabular}{|c|c|c|c|c|c|}
\hline & $\begin{array}{r}\text { Vigtaður } \\
\text { fjöldi }\end{array}$ & $\begin{array}{l}\text { Raunveru- } \\
\text { legur fjöldi }\end{array}$ & Hlutfall & $\begin{array}{r}\text { Vikmörk } \\
(+/-)\end{array}$ & Hlutfall \\
\hline Oft & 432 & 435 & $41 \%$ & $3,0 \%$ & $41 \%$ \\
\hline Stundum & 428 & 445 & $41 \%$ & $3,0 \%$ & 41\% \\
\hline Sjaldan & 157 & 155 & $15 \%$ & $2,2 \%$ & 15\% \\
\hline Aldrei & 33 & 29 & $3 \%$ & $1,1 \%$ & - 3\% \\
\hline Fjöldi svara & 1050 & 1064 & $100 \%$ & & \\
\hline Veit ekki & 154 & 143 & & & \\
\hline Vil ekki svara & 69 & 63 & & & \\
\hline Alls & 1273 & 1270 & & & \\
\hline
\end{tabular}

Marktækur munur reyndist vera innan páttanna kyn $(p<0,001)$, menntun $(p<0,05)$ og stjórnmálaflokkur $(p<0,001)$. Að mati $48 \%$ karla leyndu ráðuneytin oft upplýsingum um opinber útgjöld en $36 \%$ kvenna voru peirrar skoðunar. Hlutföllin snerust við og jöfnuðust að mestu pegar stundum var bætt í myndina. Samkvæmt 35\% karla og $48 \%$ kvenna leyndu pau stundum pess háttar upplýsingum. Tæplega 90\% svarenda með verklegt framhaldsnám eða iðnmenntun töldu ráðuneytin leyna slíkum upplýsingum oft eða stundum en lægra hlutfall peirra sem höfðu lokið framhaldsnámi í háskóla var peirrar skoðunar, eða 78\%. Rúmlega 80\% peirra sem studdu Framsóknarflokkinn og Sjálfstæðisflokkinn töldu ráðuneytin leyna pessum upplýsingum. Aftur á móti töldu 70\% samfylkingarmanna að pau gerðu pað oft eða stundum og 69\% Vinstri grænna voru peirrar skoðunar.

\subsection{Sveitarfélög og stofnanir peirra}

prír fjórðu svarenda töldu sveitarfélögin og stofnanir peirra leyna oft eða stundum mikilvægum upplýsingum sem ættu erindi við almenning og vörðuðu opinber útgjöld, sæju pau ástæður til pess ( $29 \%$ oft, $46 \%$ stundum). Einungis 3\% peirra töldu að pau gerðu pað aldrei en $22 \%$ taldi að slíkt væri sjaldan gert. 
Marktækur munur var eftir kyni $(p<0,01)$, aldri $(p<0,05)$, búsetu $(p<0,05)$, stjórnmálaflokki $(p<0,05)$ og hjúskaparstöðu $(p<0,05)$. Samkvæmt 33\% karla leyndu sveitarfélög og stofnanir peirra oft upplýsingum um opinber útgjöld en $25 \%$ kvenna töldu að pau gerðu pað oft. Hlutföll kynjanna snerust við pegar svarmöguleikinn stundum var skoðaður en $41 \%$ karla og 51\% kvenna töldu pau stundum leyna slíkum upplýsingum. Færri svarendur í yngsta aldurshópinum (18-29 ára) töldu að pessir aðilar leyndu oft eða stundum upplýsingum en svarendur í hinum fimm eldri (30 ára og eldri). Fleiri höfuðborgarbúar voru peirrar skoðunar að pessir aðilar leyndu upplýsingum en fólk á landsbyggðinni. Tæplega prír fjórðu peirra sem studdu Framsóknarflokkinn töldu sveitarfélögin og stofnanir peirra leyna slíkum upplýsingum oft eða stundum og 73\% sjálfstæðismanna töldu pau gera pað. Аð mati $67 \%$ samfylkingarmanna gerðu pau pað oft eða stundum en $72 \%$ Vinstri grænna voru peirrar skoðunar.

\subsection{Pjónustustofnanir á vegum ríkisins}

Að mati 73\% svarenda leyndu pjónustustofnanir á vegum ríkisins oft eða stundum mikilvægum upplýsingum sem ættu erindi við almenning og vörðuðu opinber útgjöld, sæju pær ástæður til pess (30\% oft, 43\% stundum). Aðeins 4\% svarenda álitu að pað gerðu pær aldrei en $22 \%$ töldu að pær gerðu pað sjaldan.

Marktækur munur var til staðar eftir kyni $(p<0,01)$, aldri $(p<0,01)$, menntun $(p$ $<0,01)$, stöðu á vinnumarkaði $(p<0,05)$, tekjum $(p<0,05)$, stjórnmálaflokki $(p<$ $0,001)$ og hjúskaparstöðu $(p<0,05)$. Að mati 37\% karla leyndu pjónustustofnanir á vegum ríkisins stundum upplýsingum sem vörðuðu opinber útgjöld en 49\% kvenna voru peirrar skoðunar. Hærra hlutfall karla taldi hins vegar að pað gerist oft, eða 34\% karla og 26\% kvenna. Færri svarendur í yngsta aldurshópinum (18-29 ára) töldu að stofnanir pessar leyndu oft eða stundum upplýsingum en svarendur í eldri aldurshópunum, einkum hinum fjórum elstu (40 ára og eldri). Samkvæmt 66\% svarenda sem höfðu bóklegt framhaldsnám að baki leyndu stofnanirnar upplýsingum en 84\% svarenda með verklegt framhaldsnám eða iðnmenntun voru peirrar skoðunar. Að mati 37\% svarenda með 200-349 púsund krónur í mánaðartekjur leyndu pessar stofnanir upplýsingunum stundum en 54\% svarenda með 350-499 púsund krónur í mánaðartekjur voru peirrar skoðunar. Hlutföllin jöfnuðust fyrir alla tekjuhópa pegar tíðnin oft og stundum var sameinuð. Tæplega prír fjórðu peirra sem studdu Framsóknarflokkinn og Sjálfstæðisflokkinn töldu pjónustustofnanirnar leyna slíkum upplýsingum oft eða stundum. Aftur á móti töldu 57\% samfylkingarmanna að pær gerðu pað oft eða stundum og 65\% Vinstri grænna voru peirrar skoðunar. 


\subsection{Eftirlitsstofnanir á vegum ríkisins}

Rúmlega 70\% svarenda töldu eftirlitsstofnanir á vegum ríkisins leyna oft eða stundum mikilvægum upplýsingum sem ættu erindi við almenning og vörðuðu opinber útgjöld, sæju pær ásææður til pess (31\% oft, 40\% stundum). Að mati 23\% svarenda gerðu pær pað sjaldan en einungis $5 \%$ peirra álitu að pær gerðu pað aldrei.

Marktækur munur reyndist til staðar eftir kyni $(p<0,001)$, aldri $(p<0,001)$, menntun $(p<0,01)$, stöðu á vinnumarkaði $(p<0,01)$, stjórnmálaflokki $(p<0,001)$ og hjúskaparstöðu $(p<0,01)$. Tæplega $70 \%$ karla töldu að eftirlitsstofnanir á vegum ríkisins leyndu oft eða stundum upplýsingum sem vörðuðu opinber útgjöld en prír fjórðu kvenna voru peirrar skoðunar. Færri svarendur í yngsta aldurshópnum (18-29 ára) töldu að stofnanir pessar leyndu oft eða stundum upplýsingum en svarendur í eldri aldurshópunum, einkum í sjötta elsta hópnum (70 ára og eldri) en par voru rúmlega $80 \%$ peirrar skoðunar. Samkvæmt $80 \%$ svarenda með verklegt framhaldsnám eða iðnmenntun að baki leyndu stofnanir pessar upplýsingunum oft eða stundum en tæplega 60\% peirra sem höfðu lokið framhaldsnámi í háskóla voru peirrar skoðunar. Rúmlega 70\% peirra sem studdu Framsóknarflokkinn og Sjálfstæðisflokkinn töldu pær leyna slíkum upplýsingum oft eða stundum. Hins vegar töldu rúmlega $60 \%$ svarenda sem studdu stjórnarflokkana að pær gerðu slíkt.

\section{Umræður}

Í samstarfsyfirlýsingu ríkisstjórnar Samfylkingarinnar og Vinstri hreyfingarinnar græns framboðs (www.stjornarrad.is/Stefnuyfirlysing/nr/303), sem mynduð var 1. febrúar 2009, er eitt af stefnumálunum að „aðgengi almennings og fjölmiðla að upplýsingum [verði] aukið“. Af pjóðfélagsumræðunni virðist mega ráða að pessi stefna njóti almenns stuðnings og ekki síður meðal stjórnarandstæðinga en stuðningsmanna ríkisstjórnarinnar. Eigi að síður virðist pað sýna sig, óháð stjórnmálaflokkum sem eru við völd hverju sinni, að pessi stefna sé, að mati kjósenda, meira í orði en á borði. Pegar á reynir virðist gegnsæið bíða lægri hlut, að mati kjósenda, og almenningur telur sig ekki njóta pess aðgengis að upplýsingum sem varða almannahagsmuni og opinber útgjöld sem ætla mætti. Í pessu sambandi er mikilvægt að árétta að rannsókn pessari er ætlað að kanna viðhorf almennings til upplýsingagjafar. Hún endurspeglar hins vegar ekki hvernig upplýsingagjöf stjórnvalda er háttað í raun og veru, pað er hvort staðreyndin sé sú að stjórnvöld leyni almenning upplýsingum, meðvitað eða ómeðvitað. Hins vegar má halda pví fram að rannsókn pessi endurspegli vantraust almennings til stjórnvalda en traustið hefur farið dvínandi á síðari árum (Bok, 2001; Capacent, 2012).

premur árum eftir að ofangreind stefna ríkisstjórnarinnar var mörkuð um aukið aðgengi almennings að upplýsingum töldu 90\% svarenda að ríkisstjórnin leyndi 
almenning oft eða stundum upplýsingum sem vörðuðu almannahagsmuni. Litlu færri, eða $88 \%$, töldu ráðuneytin starfa í sama anda. Sveitarfélögin sýndu að vísu betri niðurstöður en engu síður töldu 78\% svarenda að leyndarhyggjan réði par einnig ríkjum. Niðurstöður könnunarinnar eru dregnar saman í töflu 6.

Tafla 6. Er upplýsingum leynt? Viðhorf svarenda í hnotskurn, eftir stjórnvaldi.

\begin{tabular}{lrrrrr}
\hline & \multicolumn{3}{c}{ Almannahagsmuni } & & \multicolumn{2}{c}{ Opinber útgjöld } \\
\cline { 2 - 3 } \cline { 5 - 6 } Stjórnvald & Oft/stundum & Sjaldan/aldrei & & Oft/stundum & Sjaldan/aldrei \\
\hline Ríkisstjórn & $90 \%$ & $11 \%(9 / 2)$ & & $81 \%$ & $19 \%(15 / 4)$ \\
Ráðuneyti & $88 \%$ & $12 \%(10 / 2)$ & & $82 \%$ & $18 \%(15 / 3)$ \\
Sveitarfélög/stofnanir & $78 \%$ & $22 \%(20 / 2)$ & & $75 \%$ & $25 \%(22 / 3)$ \\
Pjónustustofnanir ríkis & $76 \%$ & $24 \%(21 / 3)$ & & $73 \%$ & $27 \%(22 / 4)$ \\
Eftirlitsstofnanir ríkis & $80 \%$ & $20 \%(18 / 2)$ & & $71 \%$ & $29 \%(23 / 5)$ \\
\hline
\end{tabular}

Stjórnmálaskoðanir og stuðningur eða andstaða við ríkisstjórn réðu töluverðu um afstöðu svarenda eins og sjá má í töflu 7. Pessi munur á afstöðu er marktækur.

Tafla 7. Afstaða svarenda m.t.t. stjórnmálaskoðana um viðhorf til upplýsingaleyndar ríkisstjórnar.

\begin{tabular}{lrrrrr}
\hline & \multicolumn{3}{c}{ Almannahagsmuni } & & \multicolumn{2}{c}{ Opplýsingar um útgjöld } \\
\cline { 2 - 3 } \cline { 5 - 6 } Stjórnmálaflokkur & Oft/stundum & Sjaldan/aldrei & & Oft/stundum & Sjaldan/aldrei \\
\hline Framsóknarflokkur & $93 \%(57 / 36)$ & $7 \%$ & & $84 \%(54 / 30)$ & $16 \%$ \\
Sjálfstæðisflokkur & $96 \%(59 / 37)$ & $4 \%$ & & $87 \%(54 / 33)$ & $13 \%$ \\
Samfylkingin & $74 \%(20 / 54)$ & $26 \%$ & & $69 \%(17 / 52)$ & $31 \%$ \\
Vinstri græn & $74 \%(18 / 56)$ & $26 \%$ & & $64 \%(13 / 51)$ & $36 \%$ \\
\hline
\end{tabular}

Pannig töldu 59\% peirra sem studdu Sjálfstæðisflokkinn að ríkisstjórnin leyndi oft upplýsingum sem vörðuðu almannahagsmuni en hlutfallið var 20\% fyrir Samfylkinguna. Hlutfallið fyrir Samfylkinguna varð hins vegar 74\% pegar stundum var lagt við en töluvert vantaði enn á pau 96\% Sjálfstæðismanna sem töldu ríkisstjórnina oft eða stundum leyna upplýsingum sem vörðuðu almannahagsmuni. Fróðlegt væri að sjá hvort pessi hlutföll snerust við með Sjálfstæðisflokkinn í ríkisstjórn og Samfylkinguna í stjórnarandstöðu.

Pessi munur kom einnig fram pegar upplýsingagjöf um opinber útgjöld var skoðuð. Pannig töldu 87\% Sjálfstæðismanna að ríkisstjórnin leyndi oft eða stundum upplýsingum um opinber útgjöld fyrir almenningi en 69\% stuðningsmanna Samfylk- 
ingarinnar töldu að svo væri. Munur á tíðni var einnig marktækur. •að sem 54\% Sjálfstæðismanna töldu að gerðist oft, töldu 52\% stuðningsmanna Samfylkingarinnar að gerðist aðeins stundum, pað er að mikilvægum upplýsingum um opinber útgjöld væri leynt.

Í pessu samhengi er áhugavert að bera saman afstöðu svarenda eftir stjórnmálaskoðunum til pess hvort sveitarfélög og stofnanir peirra leyndu upplýsingum sem vörðuðu almannahagsmuni og útgjöld. Par var lægra hlutfall stuðningsmanna Sjálfstæðisflokksins peirrar skoðunar, eða 73\%, sem rímar vel við nánast sama hlutfall Vinstri grænna, 73\%, varðandi leynd upplýsinga um almannahagsmuni og 72\% varðandi upplýsingar um útgjöld. Framsóknarmenn voru hins vegar frekar á bví að sveitarfélögin og stofnanir peirra leyndu oft eða stundum mikilvægum upplýsingum. Par var hlutfallið $81 \%$ hvað snerti upplýsingar um almannahagsmuni en $74 \%$ varðandi upplýsingar um útgjöld. Afstaðan til sveitarfélaganna var pannig ekki sú sama og gagnvart ríkisstjórninni og mildari en pegar bjóðmálin voru undir.

Pá er athyglisvert að peir sem höfðu háskólanám að baki töldu síður að upplýsingum væri leynt. Pannig töldu einungis 36\% peirra sem höfðu lokið framhaldsnámi í háskóla að ríkisstjórnin leyndi oft upplýsingum sem vörðuðu almannahagsmuni og $42 \%$ stjórnenda voru sömu skoðunar. Pað var hins vegar mat $62 \%$ fólks með iðnmenntun að petta gerðist oft. Vissulega er aðgengi manna að upplýsingum misjafnt og margir öðlast margs konar vitneskju í starfi sínu sem er ekki á almannavitorði. Pví kann að vera að pessi munur sé að einhverju leyti slíks eðlis. Peir sem sitja næst ákvörðunum og valdi pekkja svörin sem eru ef til vill ekki að á almannavitorði.

pótt menntun, starfsstétt og afstaða til stjórnmálaflokka sköpuðu vissan breytileika í afstöðu svarenda var niðurstaðan almennt sú að meginporri svarenda taldi að ríkisstjórnin og ráđuneytin leyndu almenning upplýsingum sem vörðuðu almannahagsmuni og opinber útgjöld. Pjónustustofnanir og eftirlitsstofnanir ríkisins fengu litlu betri einkunn eins undarlegt og pað kann að vera, par sem eitt meginhlutverk peirra er að upplýsa almenning. Vissulega hefur komið upp nokkur fjöldi mála á síðustu misserum par sem eftirlitsstofnanir virtust bregðast eftirlits- og upplýsingaskyldu sinni. Svo virtist sem reynt væri að fela mistökin fyrir almenningi eins og dæmin um iðnaðarsílíkon í ígræddum brjóstapúðum, kadmíum í áburði og iðnaðarsalt sem notað var í matvælaframleiðslu sýna (sjá t.d. „Iðnaðarsalt átti ekki að nota í matvæli“, 2012; Ingveldur Geirsdóttir 2012a, 2012b; „Mistök að veita ekki upplýsingar án tafar“, 2012). Pví mætti halda fram að viðhorf almennings mótuðust að einhverju leyti af opinberri umræðu hvað petta varðar og að pessi tilteknu tilvik hafi verið yfirfærð á allar eftirlitsstofnanir. Sumir svarenda kynnu að hafa dregið pá ályktun að pað sem upp kemst sé aðeins toppurinn á ísjakanum. 
Sveitarfélög og stofnanir peirra standa oft nær íbúunum en ríkisvaldið. Prátt fyrir pað töldu 78\% svarenda að pessir aðilar leyndu mikilvægum upplýsingum sem ættu erindi við íbúana og vörðuðu hagsmuni peirra. Búseta skipti hér ekki miklu máli. Höfuðborgarsvæðið og landsbyggðin komu svipað út í pessu tilliti pótt landsbyggðin hefði aðeins vinninginn. Pó töldu 75\% peirra sem bjuggu á landsbyggðinni að sveitarfélög leyndu upplýsingum oft eða stundum. Ekki er hægt að fullyrða hvort svarið átti við peirra eigið sveitarfélag eða sveitarfélög almennt.

Í netpanel Félagsvísindastofnunar er að finna ýmsar breytur sem ef til vill hefðu ekki verið valdar ef panellinn væri ekki greindur með peim hætti. Könnunin upplýsti pannig um mun á afstöðu eftir kyni og aldri sem hefði ekki verið leiddur í ljós að öðrum kosti. Svörin sýndu greinilega aftur og aftur að hærra hlutfall karla taldi aðila sem könnunin náði til leyna oft upplýsingum um almannahagsmuni. Konurnar voru hins vegar fremur peirrar skoðunar að peim væri stundum leynt. Pegar svarmöguleikarnir voru lagðir saman jöfnuðust kynjahlutföllin og yfirleitt pannig að konurnar voru fremur á pví að upplýsingum væri leynt. Hér kann að birtast í einhverjum mæli munur á konum og körlum, pað er að konur séu varfærnari í afstöðu sinni. Sama mynstur birtist pegar spurt var um leynd upplýsinga um útgjöld.

Pegar svör voru skoðuð með tilliti til aldurs kom í ljós að grunur um leyndarhyggju jókst eftir pví sem svarendur voru eldri. Hér kann uppsöfnuð lífsreynsla að koma til að einhverju marki pannig að tilvik í fortíðinni sem peir yngri pekktu jafnvel ekki til, lituðu afstöðu hinna eldri. Yngra fólk er einnig oft talið saklausara. Vera kann að yngri svarendur hefðu síður yfirfært einstök tilvik í bjóðfélagsumræðunni yfir á fleiri stofnanir pegar eldri svarendur gætu hafa gert pað.

Loks má nefna að afstaða svarenda virtist í einu tilviki breytileg eftir tekjum hvað varðaði opinber útgjöld með tilliti til pjónustustofnana ríkisins en sá munur hvarf pegar svarmöguleikarnir oft og stundum voru lagðir saman. Afstaða svarenda virtist pannig yfirleitt ekki breytast eftir tekjum.

Eins og fram hefur komið var meginporri pjóðarinnar peirrar skoðunar að stjórnvöld leyndu upplýsingum sem hana vörðuðu pegar könnunin var gerð í mars og apríl 2012. Vera kann að fjölmiðlaumræða hafi haft áhrif á svör almennings að einhverju leyti eins og fyrr er getið. Samt sem áður er athyglisvert og nokkurt áhyggjuefni að almenningur hafði pá trú að stjórnvöld leyndu upplýsingum í svo ríkum mæli sem raun bar vitni. Hvort sú afstaða var breytileg eftir fjölmiðlanotkun svarenda er ekki vitað en fróðlegt væri að nota pá breytu ef könnun sem pessi yrði gerð síðar við breyttar aðstæður í pjóðfélaginu.

Einungis 2-3\% svarenda töldu að pað gerðist aldrei að upplýsingum sem vörðuðu almannahagsmuni væri leynt en hlutfallið skánaði aðeins varðandi opinber útgjöld. Pó töldu aðeins 3-5\% svarenda að slíkum upplýsingum væri aldrei leynt. Sé gengið út frá 
pví að samhljómur sé á milli upplýsingagjafar stjórnvalda og trausts (sjá t.d. Piotrowski, 2007; Rawlins, 2007), andstætt pví sem aðrir halda fram (sjá t.d. Roberts, 2005; Cook, 2010), vekur athygli að niðurstöður könnunar sem gerð var á svipuðum tíma og pessi könnun sýndu að einungis 10\% Íslendinga báru mikið traust til Alpingis og 15\% til borgarstjórnar Reykjavíkur. Traustið til Alpingis dalaði talsvert frá pví fyrir efnahagshrunið. Í febrúar 2008 báru 42\% landsmanna mikið traust til Alpingis en 13\% í febrúar 2009 (Capacent, 2012).

Upplýsingalög tóku gildi hérlendis 1 . janúar 1997. Pau hafa verið talsvert í umræðunni undarfarið („Upplýsingalög aftur á ping“, 2012) og nú hafa ný upplýsingalög nr. 140/2012 tekið gildi. Í ljósi umræðunnar um lögin hefði mátt ætla að stjórnvöld, og einnig almenningur, væru meðvituð um tilvist, innihald og gildi laganna en ýmsir fræðimenn telja að gildistaka og tilvist upplýsingalaga bæti upplýsingagjöf og auki gegnsæi (Mendel, 2008; Stiglitz, 2003). Kannanir í Bretlandi hafa sýnt að gildistaka upplýsingalaga leiddi til aukins gegnsæis sem hafði pó ekki samtímis í för með sér aukið traust (Hazell og Worthy, 2010; Worthy, 2010). Andstæðingar upplýsingalaga hafa látið í ljós pá skoðun að leyndarhyggjan kynni jafnvel að aukast með tilkomu laganna og gæti jafnframt haft í för með sér vanrækslu hvað skjalfestingu varðar (Tough, 2011; Worthy, 2010). Könnunin sem hér er til umræðu leiddi í ljós að almenningur hér á landi taldi að upplýsingum væri leynt prátt fyrir að upplýsingalög hefðu öðlast gildi.

Síðustu áratugi hafa Íslendingar í vaxandi mæli komið sér upp lögum, reglum, leiðbeiningum og viðmiðum til stuðnings skjalfestingu, skráningu, gegnsæi, upplýsingagjöf og greiðum aðgangi að upplýsingum. Pá standa peir frammi fyrir ýmsum áskorunum hvað pessi mál varðar (sjá kafla 2.3). Svo virðist sem stjórnvöld og embættismenn fylgi ekki alltaf lögum og viðmiðum sem styðjast ætti við til aukins gegnsæis og bættrar upplýsingagjafar (sjá t.d. Jóhanna Gunnlaugsdóttir, 2011; Páll Hreinsson, Sigríður Benediktsdóttir og Tryggvi Gunnarsson, 2010, 5. bindi, kafli 16.1.2.7). Mikilvægt er að upplýsingum sé haldið til haga á viðunandi hátt pannig að pær séu óbrenglaðar, áreiðanlegar og aðgengilegar peim sem mega hafa aðgang að peim. Pví miður hefur komið í ljós að mikilvægar ákvarðanir innan stjórnvalds hafa ekki alltaf verið skjalfestar sem skyldi. Hér er til dæmis átt við hverjir tóku tilteknar ákvarðanir og hvenær. Рað kynni að vera af ótta við að upplýsingar um ákvarðanir yrðu gerðar opinberar á grundvelli upplýsingalaga. Sé raunin sú hafa upplýsingalögin í vissum tilvikum haft pveröfug áhrif og allt önnur en peim er ætlað (Jóhanna Gunnlaugsdóttir, 2005; 2009; 2011).

Pessi rannsókn styðst við fyrri rannsóknir, upplýsingar og gögn um traust til stjórnvalda, upplýsingagjöf, upplýsingalög og kröfur um gegnsæi í stjórnsýslunni. Niðurstöðurnar ættu ekki að koma á óvart íl ljósi pjóðfélagsumræðunnar, vandamála í 
kjölfar efnahagshrunsins, biðarinnar eftir raunhæfum lausnum og dvínandi trausts almennings til stjórnvalda. Rannsóknin snýst um viðhorf almennings til upplýsingagjafar en ekki um pað hvernig upplýsingagjöf stjórnvalda er háttað í raunveruleikanum. Рað væri áhugavert að skoða með frekari rannsóknum. Niðurstöður pessarar rannsóknar gætu pó orðið stjórnvöldum ábending um að bæta miðlun upplýsinga pannig að almenningur teldi sig upplýstan um mikilvæg mál. Einnig væri áhugavert að endurtaka könnun sem pessa að nokkrum árum liðnum. Pá verða aðstæður í pjóðfélaginu ef til vill aðrar en nú og athyglisverðar til samanburðar.

\section{Um höfundinn}

Jóhanna Gunnlaugsdóttir er prófessor við Félags- og mannvísindadeild Háskóla Íslands. Netfang: jg@hi.is.

\section{Heimildaskrá}

Berman, E. M. (1997). Dealing with cynical citizens. Public Administration Review, 57 (2), 105-112. http://dx.doi.org/10.2307/977058

Birkinshaw, P. (2010). Freedom of information and its impact in the United Kingdom. Government Information Quarterly, 27 (4), 312-321. http://dx.doi.org/10.1016/j.giq.2010.06.006

Bok, D. (2001). The trouble with government. Cambridge, Mass.: Harvard University Press.

Capacent (2012). Traust til stofnana skv. Pjóðarpúlsi Capacent. Vefslóð: http:/gagnatorg.capacent.is/data/set/1wb6/traust-til-stofnana-skv-thjodarpulsi-capacent

Cook, F. L., Jacobs, L. R. og Kim, D. (2010). Trusting what you know: Information, knowledge, and confidence in social security. The Journal of Politics, 72 (2), 397-412. http://dx.doi.org/10.1017/S0022381610000034

Curtin, D. og Meijer, A. J. (2006). Does transparency strengthen legitimacy? Information Polity, 11 (2), 109-123.

Dalton, R. J. (2005). The social transformation of trust in government. International Review of Sociology, 15 (1), 133-154. http://dx.doi.org/10.1080/03906700500038819

Darch, C. og Underwood, P. (2010). Freedom of information in the developing world: Demand, compliance and democratic behaviours. Oxford: Chandos.

Enn á ný leyna stjórnvöld gögnum um Icesave. (2009, 18. september). Visir.is. Vefslóð: http://www.visir.is/enn-a-ny-leyna-stjornvold-gognum-um-icesave/article/2009808825108

Fairbanks, J., Plowman, K. D. og Rawlins, B. L. (2007). Transparency in government communication. Journal of Public Affairs, 7 (1), 23-37. http://dx.doi.org/10.1002/pa.245

Fairclough, N. (1993/2002). Discourse and social change. Malden, Mass.: Blackwell.

Flinn, A. og Jones, H. (2009). Freedom of information: Open access or empty archives? London: Routledge.

Gaber, I. (2000). Lies, damn lies ... and political spin. British Journalism Review, 11 (1), 60-70. http://dx.doi.org/10.1177/095647480001100111

Grimmelikhuijsen, S. (2011). Being transparent or spinning the message? An experiment into the effects of varying message content on trust in government. Information Polity 16 (1), 35-50. 
Guðrún Pétursdóttir (ritstjóri). (2011). Jjóð til pings: Skýrsla stjórnlaganefndar 2011. (Fyrra bindi.) Reykjavík, Stjórnlaganefnd.

Hazell, R. og Glover, M. (2011). The impact of freedom of information on Whitehall. Public Administration, 89 (4), 1664-1681. http://dx.doi.org/10.1111/j.1467-9299.2011.01930.x

Hazell, R. og Worthy, B. (2010). Assessing the performance of freedom of information. Government Information Quarterly, 27 (4), 352-359. http://dx.doi.org/10.1016/j.giq.2010.03.005

Hazell, R., Worthy, B. og Glover, M. (2010). The impact of the Freedom of Information Act on central government in the UK: Does FOI work? Basingstoke: Palgrave Macmillan.

Hennink, M., Hutter, I. og Bailey, A. (2011). Qualitative research methods. Los Angeles: Sage.

Hetherington, M. (2005). Why trust matters: Declining political trust and the demise of American liberalism. Princeton, N.J.: Princeton University Press.

Hood, C. (2006). Beyond exchanging first principles? Some closing comments. Bls. 211-226 í C. Hood og D. Heald (ritstjórar), Transparency: The key to better governance? Oxford: Oxford University Press.

Hörður Ægisson. (2013, 29. janúar). Óvissu aflétt í efnahagsmálum. Morgunblaðið, bls. 20.

Iðnaðarsalt átti ekki að nota í matvæli. (2012, 17. janúar). Fréttablaðið, bls. 8.

Ingibjörg Lilja Ómarsdóttir. Vefpóstur, 16. október 2012.

Ingveldur Geirsdóttir. (2012a, 12. janúar). Engin skráning er á lækningatækjum. Morgunblaðið, bls. 16. Ingveldur Geirsdóttir. (2012b, 18. janúar). Lýtalæknar sitja á upplýsingum um sílíkonaðgerðir.

Morgunblaðið, bls. 2.

Jóhanna Gunnlaugsdóttir. (2005, 17. febrúar). Skjöl skelfa. Morgunblaðið, bls. 34.

Jóhanna Gunnlaugsdóttir. (2009, 23. mars). Minnisblöð embættismanna. Fréttablaðið, bls. 3 [eldhúsdagur].

Jóhanna Gunnlaugsdóttir. (2011, 1. desember). Gegnsæ stjórnsýsla og rétturinn til upplýsinga. Tölvumál (vefútgáfa). Varðveitt á vefslóðum: http://hdl.handle.net/1946/10320 og http://www.sky.is/item/1582-gegnsæ-stjórnsýsla-og-rétturinn-til-upplýsinga

Kjær, A. M. (2004). Governance. Malden, Mass.: Polity Press.

Levi, M. og Stoker, L. (2000). Political trust and trustworthiness. Annual Review of Political Science, 3 (1), 475-507. http://dx.doi.org/10.1146/annurev.polisci.3.1.475

Liu, B. F., Horsley, J. S. og Yang, K. (2012). Overcoming negative media coverage: Does government communication matter? Journal of Public Administration Research and Theory, 22, 597-621. http://dx.doi.org/10.1093/jopart/mur078

Margetts, H. (2006). Transparency and digital government. Bls. 197-207 í C. Hood og D. Heald (ritstjórar), Transparency: The key to better governance? Oxford: Oxford University Press.

Mendel, T. (2008). Freedom of information: A comparative legal survey (2. útgáfa). París: UNESCO.

Mistök að veita ekki upplýsingar án tafar. (2012, 6. janúar). Fréttablaðið, bls. 10.

Neuman, W. L. (2011). Social research methods: Qualitative and quantitative approaches (7. útgáfa). Boston, Mass.: Pearson.

Norris, P. (2001). Digital divide: Civic engagement, information poverty, and the Internet worldwide. Cambridge: Cambridge University Press.

O'Neill, O. (2002). A question of trust: The BBC Reith Lectures 2002. Cambridge: Cambridge University Press.

Páll Hreinsson, Sigríður Benediktsdóttir og Tryggvi Gunnarsson. (2010). Aðdragandi og orsakir falls islensku bankanna 2008 og tengdir atburðir. Reykjavík: Rannsóknarnefnd Alpingis. 
Pew Research Center for the People and the Press. (2010). The people and their government: Distrust, discontent, anger and partisan rancor. Washington: Höfundur. Vefslóð:

http://www.people-press.org/files/legacy-pdf/606

Pierson, P. (2000). The limits of design: Explaining institutional origins and change. Governance 13 (4), 475-499. http://dx.doi.org/10.1111/0952-1895.00142

Piotrowski, S. (2007). Governmental transparency in the path of administrative reform. Albany: State University of New York Press.

Rawlins, B. (2007). Trust and PR practice. Grein á vefsíðu Institute for Public Relations, Gainesville, Florida. Vefslóð: http://www.instituteforpr.org/topics/trust-and-pr-practice

Relly, J. E. og Sabharwal, M. (2009). Perceptions of transparency of government policymaking: A cross-national study. Government Information Quarterly, 26 (1), 148-157. http://dx.doi.org/10.1016/j.giq.2008.04.002

Roberts, A. (2005). Spin control and freedom of information: Lessons for the United Kingdom from Canada. Public Administration, 83 (1), 1-23. http://dx.doi.org/10.1111/j.0033-3298.2005.00435.x

Saunders, M., Lewis, L. og Thornhill, A. (2003). Research methods for business students (3. útgáfa). New York: Prentice Hall.

Screene, L. (2005). How prepared are public bodies for the implementation of the UK Freedom of Information Act, in January 2005? Records Management Journal, 15 (1), 34-42. http://dx.doi.org/10.1108/09565690510585411

Shepherd, E. og Ennion, E. (2007). How hast the implementation of the UK Freedom of Information Act 2000 affected archives and records management services? Records Management Journal, 17 (1), 32-51. http://dx.doi.org/10.1108/09565690710730688

Shepherd, E., Stevenson, A. og Flinn, A. (2010). Information governance, records management, and freedom of information: A study of local government authorities in England. Governance Information Quarterly, 27 (4), 337-345. http://dx.doi.org/10.1108/09565690710730688

Snell, R. (2002). FoI and the delivery of diminishing returns, or how spin-doctors and journalists have mistreated a volatile reform. The Drawing Board: An Australian Review of Public Affairs, 2 (3), 187-207. Vefslóð: http://www.australianreview.net/journal/v2/n3/snell.pdf

Sigurður Kári Kristjánsson. (2010, 16. júní). Rannsókn á Icesave-málinu. Morgunblaðið, bls. 17.

Stiglitz, J. (2003). Transparency of government (part 1) - breakthrough for reforming the shape of a nation. Ritgerð birt á vefsíðu Research Institute of Economy, Trade and Industry í Japan.

Vefslóð: http://www.rieti.go.jp/en/special/economics-review/013.html

Stígur Helgason og Trausti Hafliðason. (2010, 23. nóvember). Upphæðin hvergi útskýrð. Fréttablaðið, bls. 6.

Stjórnlagarád. (2011). Pjóð til pings: Frumvarp til stjórnskipunarlaga [smárit]. Reykjavík: Höfundur. Vefslóð: http://www.stjornlagarad.is/other_files/stjornlagarad/Frumvarp_med_skyringum.pdf

Tough, A. (2011). Accountability, open government and record keeping: Time to think again? Records Management Journal, 21 (3), 225-236. http://dx.doi.org/10.1108/09565691111186894

Upplýsingalög aftur á ping. (2012, 11. október). Viðskiptablaðið, bls. 10.

Vleugels, R. (2011, 9. október). Overview of all FOI laws. Fringe Special. Vefslóð: http://right2info.org/resources/publications/Fringe Special - Overview FOIA - sep 20 2010.pdf

Worthy, B. (2010). More open but not more trusted?: The effect of the Freedom of Information Act 2000 on the United Kingdom central government. Governance, 23 (4), 561-582. http://dx.doi.org/10.1111/j.1468-0491.2010.01498.x 